\title{
FLUORESCENT PSEUDOMONADS ASSOCIATED WITH THE RHIZOSPHERE OF CROPS - AN OVERVIEW
}

\author{
Gloria R. Botelho $^{1 *}$; Leda Cristina Mendonça-Hagler² \\ ${ }^{1}$ Laboratório de Ecologia Microbiana, Empresa Brasileira de Pesquisa Agropecuária, Centro Nacional de Pesquisa de \\ Agrobiologia, Rio de Janeiro, RJ, Brasil; ${ }^{2}$ Laboratório de Ecologia Microbiana e Taxonomia, Instituto de Microbiologia Prof. \\ Paulo de Góes, Centro de Ciências da Saúde, Universidade Federal do Rio de Janeiro, Rio de Janeiro, RJ, Brasil
}

Submitted: January 09, 2006; Returned to authors for corrections: March 23, 2006; Approved: July 18, 2006

\begin{abstract}
Environmental concerns have led to the need of sustainable use of natural resources. The conventional agriculture caused considerable impacts on soils and waters. It is important to change certain agricultural managements to environmental cleaner techniques. The sustainable agriculture has pointed many approaches and techniques to reduce environmental impact. One of those strategies is the utilization of the soil microbiota to induce plant growth, control of plant diseases and biodegradation of xenobiotic compounds. Studies on the relationship between roots and microbiota are essential to achieve viable agricultural applications. These studies indicate that one of the most abundant microorganisms in the rhizosphere (area around the roots) is fluorescent Pseudomonas spp. They have been considered as an alternative to agrochemicals for controlling plant diseases and increasing plant development. This review addresses the main findings on fluorescent Pseudomonads. It summarizes and discusses significant aspects of this general topic, including (i) rhizosphere as a microhabitat; (ii) taxonomic, genetic and ecological aspects of fluorescent Pseudomonads in the rhizosphere; (iii) mechanisms of Plant Growth Promoting and Biological Control and (iv) commercial use of PGPR in agriculture.
\end{abstract}

Key words: plant growth promoting, biological control, fluorescent Pseudomonads, rhizosphere

\section{RHIZOSPHERE AS A MICROHABITAT}

Roots alter chemical and physical characteristics of soil and make it a specialized habitat that increases the microbiota community. This community influence is important since roots absorb water and nutrients and pathogens can go into the plants.

The term rhizosphere, proposed by Hilter one hundred years ago, was initially defined as the soil area under the influence of plant roots. Subsequent studies concluded that the rhizosphere consists of three different regions: endorhizosphere which composes of the root tissues; rhizoplane is the root bidimensional surface and ectorhizophere, which represents the adjacent soil $(74,89)$. However, the endorhizosphere term has been avoided (65) because, semantically, it could determine a zone of the ecological niche and not exactly a niche inside the plant. Beyond that there is not a standard term and it can confuse the precise determination of the ecological niche and the microbial groups on it. Finally, authors proposed the elimination of the term. Nowadays, rhizosphere and rhizoplane are the terms to describe external niches to the roots and there is divergence of terms to define the internal niche.

Microbial community increases from outside to inside roots (89). Closer biochemical interactions between microorganisms and plants are related to that increment in the community (89). The bacteria that inhabit inner tissues of roots are called endophytic bacteria. There are different definitions to the "endophytic microorganism" term (7,65). Wilson (164) defined

*Corresponding Author. Mailing address: Laboratório de Ecologia Microbiana, EMBRAPA, CNPAB, Rodovia BR 465, km 7. 23890-000, Rio de Janeiro, RJ, Brasil. Tel. (+5521) 2682-1500 Ext. 211, Fax: (+5521) 2682-1230. E-mail: gbotelho.rlk@terra.com.br and gloria@cnpab.embrapa.br 
as endophytic microorganisms, bacteria and fungi that fully colonize inner tissues of plants during part or all their life cycle without causing disease symptoms. This definition is considered appropriated to define these microorganisms (109). Bacteria genera, such as Pseudomonas, Azospirillum, Acetobacter, Herbaspirillum, Bacillus are described as endophytic bacteria $(7,109)$.

The microorganisms mainly colonize the root cap, epidermis and cortex. The root cap produces mucilage that protects against desiccation and adheres to soil and microorganisms that can use it as nutrient source. The mucilage amount and composition depends on the plant species. In corn, the polysaccharide is basically constituted of $\beta$ 1-4 glucan with hydrophilic polymers of galactose and fucose and lesser quantity of xylose, arabinose, galacturonic acids, some phenolics and proteins (89). Fucose that occurs in the mucilage and in layers of corn root cap cell walls is important in host - pathogen - symbiosis recognition systems. (e.g. Azospirillum lipoferum). Mandimba et al. (90) observed specific chemotaxis of diazotrophic maize isolates to maize mucilage. Cells released from root cap can also supply nutrients to the microorganisms. Corn roots can release approximately 10.0000 cells/day (89).

Mostly bacteria colonize the epidermis and the root hairs. These bacteria produce mucilage that is similar to pectin (polygalacturonic acid). They are present in intercellular spaces of the cortex and can penetrate the cells. Saprophytic microorganisms, as Pseudomonas fluorescens, can colonize dead cortical cells of pea roots (22).

Nutrient availability is the base for root colonization. That availability is the photosynthetic translocation from leaves to roots that are released to soil. The rhizodeposition is considered the main carbon source to soil (167). The amount of rhizodeposition changes according to the plant species and the environmental conditions. Values from 10 to $100 \mathrm{mg}$ of Carbon/g of root dry weight or $20 \%$ of photosynthates has been cited (167). The rhizodeposited materials can be small watersoluble organic compounds or complex compounds, as flavonoids. Those materials are grouped as: exudates that are water-soluble, which flow from the roots without involving metabolic energy; secretions that are high molecular weight compounds, which depend upon metabolic processes; lysates released from cells autolysis that include cell walls or even whole cells; and gases such as ethylene and $\mathrm{CO}_{2}$ (167). These rhizodeposited materials stimulate and select the soil microbial communities associated to the plant rhizosphere. Among them, bacterial community is the most influenced (89). The rhizosphere effect is not group specific and it can influence different morphological, physiological and taxonomic groups. Nevertheless, the short gram-negative rods represent significant part of the bacteria associated with the rhizosphere. These organisms propagate very quickly, are able to use aminoacids and water-soluble sugars and are resistant to some antibiotics (1). Generally Pseudomonas, Flavobacterium, Alcaligenes and Agrobacterium are especially common in the rhizosphere (1). The nutritional versatility of the genera Pseudomonas is described in many reports $(99,113)$. Pillai and Swarup (127) studied the catabolism of flavonoid in a strain of $P$. putida. They observed that the strain was able to utilize a wide range of flavonoids, including flavonols, flavones and isoflavones. Benizri et al. (10) observed that exudates of maize rhizosphere can influence in the production of indol acetic acid by a strain of $P$. fluorescens. The microbe utilization of the exudates, especially amino acids and sugars, may be important to the plant development and yield.

The rhizosphere effect on the Pseudomonads was detected after twenty days cycles of the soybean growth (17). It was observed significant increase in the total fluorescent Pseudomonads community and the in phenazine (antibiotics) producers after each cycle, characterizing an accumulative effect (Fig. 1).

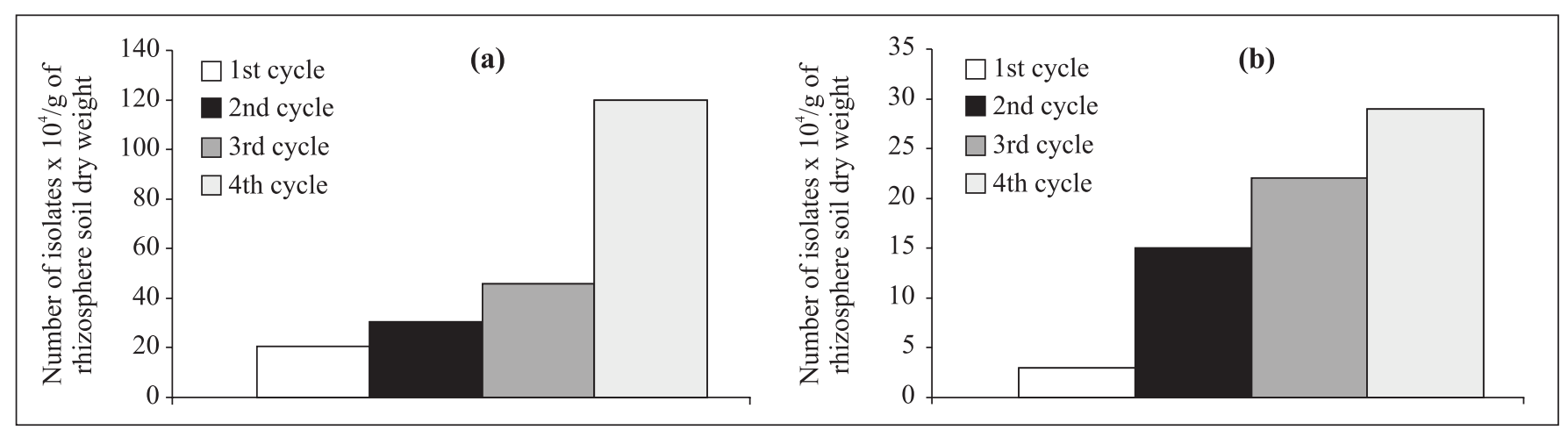

Figure 1. Fluorescent Pseudomonads community in the rhizosphere: (a) total community of fluorescent Pseudomonads; (b) phenazine producers $-\mathrm{Phz}+(2,17)$. 


\section{FLUORESCENT PSEUDOMONAS TAXONOMIC STATUS}

The genus Pseudomonas belongs to the $\gamma$ subclass of the Proteobacteria and includes mostly fluorescent Pseudomonads as well as a few non-fluorescent species. Fluorescent Pseudomonas group represents: 1) phytopathogenic cytochrome c oxidase-positive species, such as $P$. cichorii, $P$. marginalis and P.tolaasii; 2) non-phytopathogenic, non-necrogenic strains, such as P.fluorescens, P.putida, P. chlororaphis, P.aureofaciens and $P$. aeruginosa type species; 3 ) phytopathogenic necrogenic fluorescent Pseudomonas spp without cytochrome c oxidase: $P$. syringae and $P$. viridiflava. Non-fluorescent $P$ seudomonas group constitutes of $P$. stutzeri, $P$. mendocina, $P$. alcaligenes and $P$. pseudoalcaligenes $(15,51,115)$. This topic specifically will focus on fluorescent Pseudomonads because they are present in many environments, especially in the plant rhizosphere. Many studies involve these bacteria that are able to improve plant growth and plant health and are implicated in the natural supressiveness of certain soils to many soil-borne diseases (163) whereas others participate in the biodegradation of natural and man-made toxic chemical compounds.

Phenotypic characterization has been used to cluster and identify bacteria according to some features such as morphology, pigmentation, and reactions to dyes and nutritional requirements. Nutritional properties were examined in a collection of 267 nonphytopathogenic Pseudomonas strains of different origins, among which 175 were fluorescent Pseudomonads. It was observed that $P$. fluorescens and $P$. putida are very heterogeneous. $P$. putida was subdivided into biotypes A and B, which became biovars A and B. P. fluorescens was also subdivided into 7 biotypes. The biotypes A, B, C, D and F were then called biovars (bv. I to $\mathrm{V}$ ) and biotypes $\mathrm{D}$ and $\mathrm{E}$ became the $P$. chlororophis and $P$. aureofaciens, respectively (116) which were then clustered as the $P$. chlororaphis (60). P. fluorescens bv. V includes strains that often cannot be classified because properties that are essential for the differentiation from other biovars are not identified. This system of multiple biovars reveals a high phenotypic heterogeneity, and probably reflects high genomic diversity. Phenotypic studies revealed this high variability with these two species, which resulted in subdivision in these biovars and sub-grouped of each one $(46,57,71,74,142)$. To elucidate the real taxonomic condition of these subgroups it is important to characterize genotypically the species and biovars. DNA-rRNA hybridization studies led to the delineation of the genus Pseudomonas into five homology groups (117). The genus Pseudomonas sensu stricto corresponds to the Palleroni sensu rRNA homology group I and contains all the fluorescent species $(115,116)$. Different studies show very high genomic variability within biovars of $P$. fluorescens and $P$. putida and probably some biovars correspond to undescribed species $(25,117,118)$. Bossis et al. (15) also got similar results. The level of similarity of rhizosphere isolates identified as $P$. fluorescens or P. putida, by the phenotypic criteria of Palleroni (116) was never greater than 55\% as compared with the type strains of $P$. fluorescens and P. putida (15).

Future studies on the ecology of fluorescent Pseudomonads require reliable, fast and cheap methods to identify large numbers of isolates. The description of new species within the distinct species P. fluorescens and P. putida remains to be done in order to elucidate the taxonomic status of this group.

\section{GENETIC CHARACTERIZATION OF PSEUDOMONADS}

The nucleotide sequences of various genes, especially those of small-subunit (SSU) rRNA has been widely used to identification and classification of microorganisms (165). The study of SSU rRNA sequences resulted in many findings, such as the Archaea, a group of prokaryotes that is separated from Bacteria. This gene is most widely used. Its sequence is a mosaic of highly conserved regions interspersed with variable and hypervariable stretches that makes it convenient for PCR primer design $(50,144)$. The $16 \mathrm{~S}$ rRNA gene from Pseudomonas spp contains 1492 nucleotide positions, of which 148 are variable and 65 positions of these are within three hypervariable regions (101). The "Pseudomonas hypervariable (hv) regions" were defined as: hv 1, E. coli $16 \mathrm{~S}$ rRNA gene sequence positions 7195; hv 2, E. coli 16S rRNA gene sequence positions 455 - 475; and hv 3. E. coli $16 \mathrm{~S}$ rRNA gene sequence positions 998-1043 $(43,101)$. These positions are located, respectively, within the regions V1: helix 6, V3: helix 18 and V6: helices P35-1 and P35-2 $(43,104)$. The regions hv1 is considered one of the most variable sequences in $16 \mathrm{~S}$ rRNAs of bacteria across the phylogenetic spectrum $(49,165)$ and is useful for differing intrageneric lineages and discerning the type strains of some species of Pseudomonas (101). Godfrey and Marshall (43) used primers based in these regions to study the diversity of Pseudomonads isolates from different parts of the world. By this approach they could detect Pseudomonads from different species in the soil from containers that arrived in New Zealand.

The large database of $16 \mathrm{~S}$ rRNA sequences is important for the analysis of environmental isolates and recognition of new sources of diversity (101). Nevertheless, there are some pitfalls in the use of rDNA for studies of biodiversity (42). The gene size is constant and consequently different genes could not be easily separated by size. In addition, inspite of the $16 \mathrm{~S}$ genes have hypervariable and extremely informative regions. They are often not divergent enough to separate in close relationships $(42,107)$. Fonseca (38) analyzed around 80 isolates of fluorescent Pseudomonads from rhizosphere of carrot and lettuce planted in consortia. Phenotipycal analysis indicated that the major part of the isolates was Pseudomonas putida. Nevertheless, the genotypic analysis by restriction of $16 \mathrm{~S}$ genes did not properly 
differentiate among the isolates because the profiles were very similar. Other techniques are utilized to solve these limitations for characterizing isolates from the environment. The region located between the 16S and 23S (ITS1) rRNA genes is very variable in size and sequence even within closely related taxonomic groups (50). Size pattern can characterize different communities of Eubacteria or Archaea and the widely divergent sequence allows the detection of species-like units very precisely by PCR, oligo-probes or long DNA probe hybridization $(42,58)$. Locatelli et al. (77) designed a set of primers specific for Pseudomonas that allowed the amplification of ITS1 together with a significant part of $16 \mathrm{~S}$ rDNA. The primers were conserved for all the Pseudomonas sequences tested and they showed specificity and efficiency for the amplification of 1100 to 1300 bp fragment to the Pseudomonas spp. This set of primers was tested to genotypic characterization of fluorescent Pseudomonads from an agroecological system in Rio de Janeiro State. They were isolated from lettuce and carrot rhizosphere. It was distinguished many groups, indicating diversity of that community and certain groups were closely related to the plants (16). It was possible to observe the specificity for plants and parts of the rhizosphere. These results suggested that those isolates could better survive and compete in the rhizosphere and consequently are more efficient Plant Growth Promoting Rhizobacteria (PGPR) and/or Biological Control Agents (BCA).

Interspersed repetitive DNA sequence elements are present in prokaryote genomes and can be used as primers sites for genomic DNA amplification $(30,157)$. Three families of repetitive sequences have been studied in most detail, including the 35 - 40 bp Repetitive Extragenic Palindromic (REP) sequence, the 124-127 bp, Enterobacterial Repetitive Intergenic Consensus (ERIC) sequence and the $154 \mathrm{bp}$ BOX element comprised of three subunits (boxA, boxB and boxC) $(30,87)$. These sequences are located in distinct, intergenic positions all around the chromossome. Louws at al. (81) demonstrated that REP, ERIC and BOX-PCR, referred to as rep-PCR collectivelly, were useful for the rapid molecular characterization of plant pathogenic bacteria, like Xanthomonas and Pseudomonas, especially at the pathovar level. Pseudomonad isolates from soybean rhizosphere cultivated in a Brazilian savannah area were analysed by BOX (Fig. 2) and ERIC - PCR (17). It was observed that the major part of them had similar profile to the strain 2-79 (Pseudomonas fluorescens). This strain was characterized as a phenazine-producer (PCA-Phenazine-1-Carboxilic Acid), antibiotic involved in supression of "Take-all" disease in wheat (151). It is important to comment that most part of the Brazilian isolates had positive reaction to the presence of $p h z C$ and $p h z D$ genes (Fig. 3b). Fragments related to PCA gene synthesis obtained by PCR from an isolate showed $96 \%$ identity to phenazine gene fragment of strain 2-79 (17) (Fig. 3a). It suggested that it is the same gene for the antibiotic synthesis. This result is in agreement with the hypothesis that $p h z$ genes are conservative among $P$. fluorescens, P. aureofaciens and P. chlororaphis (161).

Many other approaches are used to analyze the diversity of the Pseudomonads. Delorme et al. (33) studied the membrane bound nitrate reductase $(\operatorname{nar} G)$ and nitrous oxide reductase (nosZ) genes diversity, implicated in the denitrification process. They compaired the similarity indexes of the $\operatorname{nar} G$ and nos $Z$ genes in different strains and the genes led to the identification of two different groups of strains. The first group presented similarity between the genes suggesting similar evolutionary pathway. The second group, on the other hand showed higher diversity of the nos $Z$ gene compared to the narG gene, suggesting different evolutionary rates.

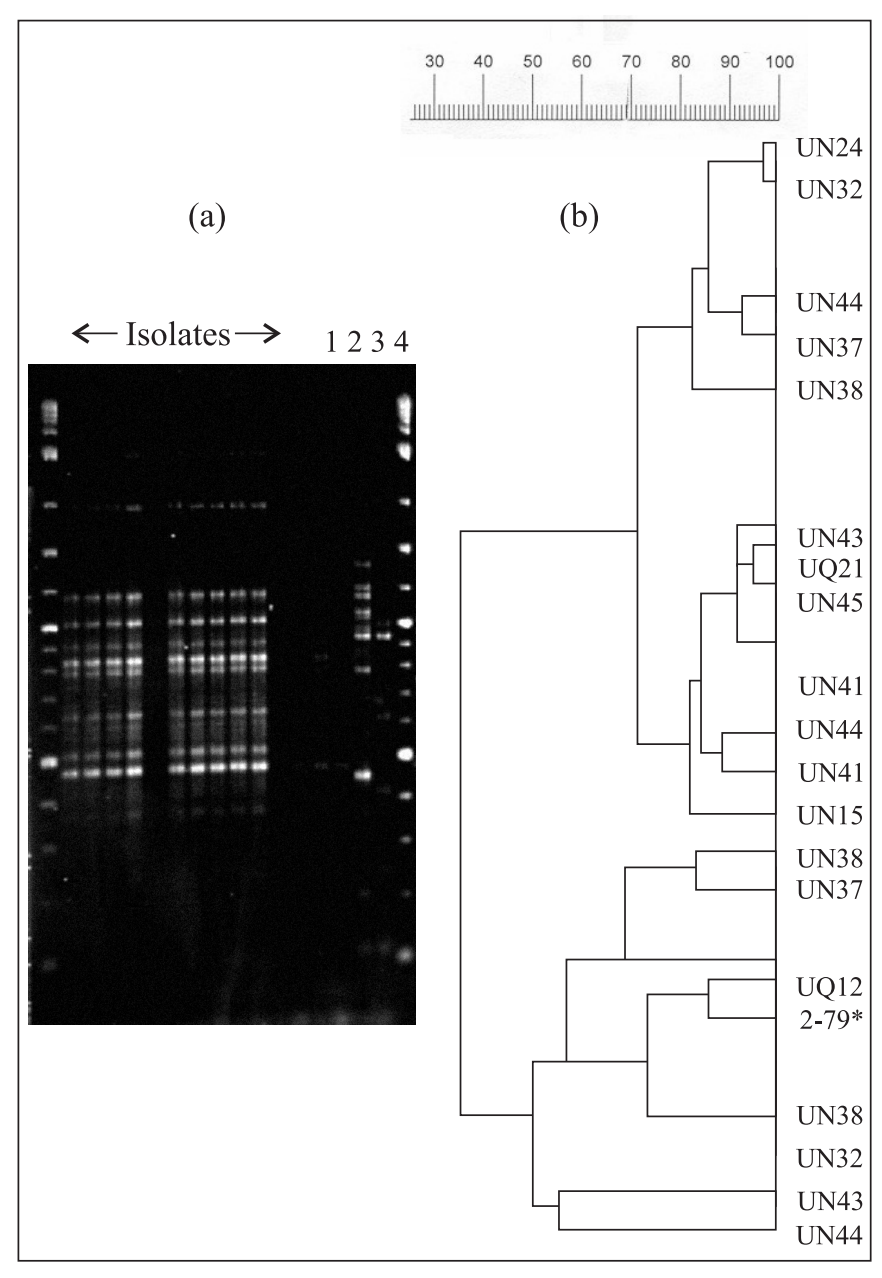

Figure 2. Genotypic characterizartion by BOX - PCR of fluorescent Pseudomonas from Brazilian soil savannah. (a) Fingerptinting of some isolates - 1, 2, 3, 4 are antibiotic producer strains of fluorescent Pseudomonas; (b) Similarity dendrogram by UPGMA; * P. fluorescens strain 2-79. 
UN411: ggcgacatgttcaacggtccgcgacgctgtcctcggccatcggcagcatgatgcgcaacg 60

2-79: ggcgacatggtcaacggtc-gcgacgctgtcctcggccatcgccagcatgatgcgcaacg 3311

$* * * * * * * * * * * * * * * * * * * * * * * * * * * * * * * * * * * * * * * * * * * * * * * * * * * * * * * * * * *$

UN411: cttggtacgaggctatcgcgecgcccaggacatcatgcaacacctgggatggaaggaacc 120

2-79: cttggtacgaggctatcgegecgccaggacatcatgcaacacctgggatggaaggaacc 3371

***************************************************************

UN411:.gtccggccaggagcagctcaccggctcccetgcctggaccagtcacgagatgctggtgct 180

2-79: gtccggccaggagcagctcaccggctcccetgcctggaccagtcacgagatgctggtgct 3431

$* * * * * * * * * * * * * * * * * * * * * * * * * * * * * * * * * * * * * * * * * * * * * * * * * * * * * * * * * * * * *$

UN411: cgactacgaactgccgcaagtacgccgggacgaacagggccgcacatttctcggttctac 240

2-79 : cgactacgaactgccgcaagtacgecgggacgaacagggecgcacatttctcggttctac 3491

**********************************************************************

UN411: ccactggccgtggantggcgagcgtacccgtcagttgacgggegctcacgnagcgetgct 300

2-79: ccactggccgtggattggcgagcgtacccgtcagttgacgggcgctcacgtagcgctgct 3551

*************** *************************************************

UN411: caccgaagngctcaacccggtggcctgcaaggtcgg-ccggatatcaccccaggatcant 359

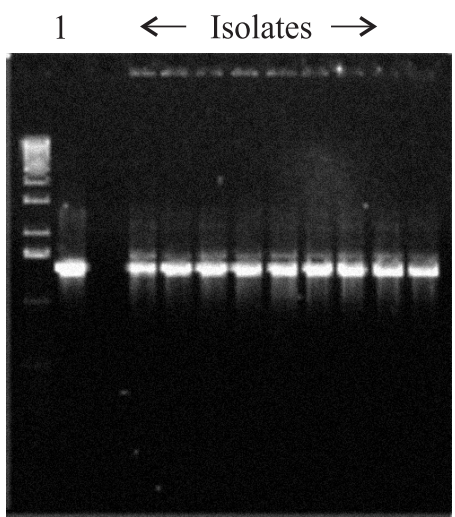

(b)

2-79 : cagcgaagtgctcaacceggtggcctgcaaggtcggcccggatatca-cccaggatcagt 3610

********* ***************************** $* * * * * * * * * * * * * * * * * * * * *$

UN411: tnctgagcetgtgcgagcgecnggacccangcgcgnacc 399

2-79: tactgagcetgtgcgagcgectggaccccaggcgegaacc 3650

$* * * * * * * * * * * * * * * * * * * * * * * * * * * * * * * * * * * *$

(a)

Figure 3. (a) - Alignment of nucleotide sequences of Phenazine-1-Carboxilic Acid (PCA) genes from an isolate of Brazilian savannah and strain 2-79 - (*) indicates identical nucleotides; (b) Detection of genes for phenazine production (1 - P. fluorescens strain 2-79 - fragment size: 1,4kb) (17).

\section{ECOLOGICALASPECTS OF PSEUDOMONADS IN THE RHIZOSPHERE}

The association between microorganisms and roots can be beneficial, neutral or harmful, but often the effects depend on the soil conditions (112). The main objective in understanding the rhizosphere effect is to increase the balance of beneficial over the harmful microbes. Nevertheless, high capacity of colonization and competition is necessary for the establishment of these organisms. Colonization potential is related to the support of nutritional balance from roots to microbes, as well as, the genes related to rhizosphere colonization (14). Exudates are readily available for microorganisms and increase their number and activity in the rhizosphere (89) and competition ability of microorganisms is related to microbes capacity of using these excreted compounds (74). Some studies have shown that organic acids form the nutritional basis of rhizosphere colonization. A defect in the utilization of organic acids, which form the major group of tomato exudate components, results in decreased competitive colonization of the tomato rhizosphere (14), whereas a defect in the use of sugars does not result in a colonization defect (84). Some genes are involved rhizosphere colonization. Rainey (131) described a method called promotertrapping technology (IVET) that enables the isolation of Pseudomonas fluorescens genes that showed high levels of expression in the rhizosphere. This method identified 20 genes that were induced during rhizosphere colonization and the models of expression were analyzed. Fourteen genes showed significant homology to sequences in GenBank that are involved in nutrient acquisition, stress response, or secretion; six showed no homology. Seven of the rhizosphere-induced (rhi) genes have homology to known non- Pseudomonas genes.

The microorganisms mainly colonize lateral roots and older parts of the root. They are grouped as opportunists that predominate on fresh roots and strategists that are more specialized and predominate on older roots (140). This last group 
of bacteria is denominated Plant Growth Promoting Rhizobacteria (PGPR). This term describes bacteria well adapted to root environment and distinguishes soil bacteria that are not able to colonize them (137).

Many bacteria genera are described as PGPR (102). Many members of genera Pseudomonas perform beneficial effects on plants $(17,20,76,137)$. Among them $P$. putida and $P$. fluorescens are fluorescent Pseudomonas species that represent significant part of these members $(52,137)$. The bacteria and roots association has been intensively reported $(74,89,102)$. Lemanceau et al (74) analyzed the root colonization by native fluorescent Pseudomonads. The study characterized genetically and phenotypically strains isolated from bulk soil, rhizosphere, rhizoplane and root tissue from tomato and flax. It concluded the plant has selective influence on fluorescent Pseudomonads community and the selection intensity varies according to the plant. Major part of the flax isolates was different from those selected from bulk soil and the difference increased when observed closer to the roots. This effect was less significant at tomato roots. Root tissues analysis indicated that the main Pseudomonads species in flax is Pseudomonas putida bv. A and in tomato is P. fluorescens bv. II. Araújo et al (4) observed that fluorescent Pseudomonas were able to compete onto the rhizoplane of maize. The increase in the heterotrophic and total of gram negative communities indicated this competition ability. In addition, they observed that $30 \%$ of isolates were identified as $P$. fluorescens and $50 \%$ were classified as $P$. putida. It was observed that $P$. putida was prevalent in the Pseudomonad community inhabiting the rhizospheres of a consortia cultivation of lettuces and carrots $(38,39)$. The prevalence of these organisms is related to its fast colonization ability (111) and its capacity of producing secondary metabolites (150). Certain metabolites, such as antibiotics, play an important role in the fluorescent Pseudomonads survival. Mazzola et al (94) reported that phenazines, a group of antibiotics produced by fluorescent Pseudomonads, contributed to the survival and capacity of competition by $P$. fluorescens strain 2-79 and $P$. aureofaciens strain 30-84. The antibiotics have excellent activity against a variety of microorganisms, including a number of fungi and bacteria that commonly occur in the rhizosphere of wheat and increased their ability to compete with the native microbiota. The production of these metabolites is considered the most important mechanism for plant disease control (149).

Denitrification process and production of pyoverdine seemed to be involved on the ability of Pseudomonads to compete in the rhizosphere. Mirleau et al. (98) observed that nitrate reductase and pyoverdine defective mutants were significantly less competitive than the wild type strain in the rhizosphere or in the bulk soil. Delorme et al. (33) suggested that Pseudomonads strains that had both genes for denitrification process (narG and nosZ) would better survive in the soil environment. That observation was reinforced in the results obtained in laboratory experiments. Fluorescent Pseudomonad total denitrifiers showed the best rhizosphere competence. Several studies have been done about the effect of plant on the microbial community. The effect on the dynamics, composition and activities of native bacterial populations, specially the components that have antagonistic action $(12,44)$. Nowadays, several studies have been focusing on this topic $(11,122,129)$. Gomes et al. (44) studied the bacterial diversity of the rhizosphere of two cultivars of maize by TGGE (Temperature Gradient Gel Electrophoresis). They observed that the rhizosphere effect was higher in the young plants compared to mature plants. Presence of Pseudomonads was representative in the rhizosphere community, despite it was not dominant. Bergsma-Vlami et al. (12) analyzed the dynamics, genotypic diversity and activity of 2,4diacetilphluoroglucinol (DAPG) producer Pseudomonas spp. in the rhizosphere of four plants cultivated in two different soils. DAPG is an important antibiotic, produced by some fluorescent Pseudomonads, to the control of plant diseases caused by fungi. $(128,129,161)$ They observed relative high population of DAPG producer Pseudomonas spp. $\left(10^{4}\right.$ a $10^{6}$ Colony Forming Units/g of roots) in the rhizosphere of the plant species, except to lily. Nevertheless, lily rhizosphere supported, on average, the highest population densities of fluorescent $P$ seudomonas spp. Similar density population was observed in the wheat rhizosphere cultivated in suppressive soil to Gaeumannomyces graminis var. tritici $(34,130)$ and in the pea rhizosphere cultivated in suppressive soil to Fusarium oxysporum f. sp. pisi (70). Bergsma-Vlami et al. (12) analyzed the DAPG producer genotypic diversity by means of DGGE (Denaturing Gradient Gel Electrophoresis). They observed a total of seven genotypic groups, some of them found only in the rhizosphere of specific plant specie. Those results showed the influence of host plant in the dynamics and composition of that community. Berg et al (11) analyzed the bacterial community of potato rhizosphere and phyllosphere. The most significant species of all microenvironments was Pseudomonas putida, and rep-PCR with BOX primers showed that those isolates showed microenvironment-specific DNA fingerprints. $P$. putida isolates from the rhizosphere and endorhiza gave nearly identical fingerprints confirming the high similarity of bacterial populations. The presence of phlD gene was evaluated also. It was found only among Pseudomonas spp. isolates from the rhizosphere and endorhiza, but not in the phyllosphere.

Another important approach is the study of the dynamics of introduced population in the microbial rhizosphere community. Lottmann et al. (80) observed the establishment of introduced bacteria in the rhizosphere of potatoes. The DGGE pattern of rhizosphere and geocaulosphere communities did not show differences between the 
inoculated and non-inoculated potatoes. It was also observed that introduced strains did not become a dominant member of the bacterial community. In other study, the effect of co- inoculation of two strains of $P$. fluorescens and arbuscular mycorrhizal fungi were evaluated on tomato rhizosphere. Both the fluorescent Pseudomonads and the myco-symbiont improved the plant growth and, depending on the inoculum combination, it strongly affected root architecture. One of the strains increased mycorrhizal colonization, suggesting that it was a mycorrhization helper bacterium (41). The co - inoculation of fluorescent Pseudomonas and Rhizobium also improved plant growth in terms of shoot height, root length and dry weight in pea. Both the fluorescent pseudomonads and Rhizobium exhibited a wide range of antifungal activity against pathogens specific to pea (69).

\section{MECHANISMS OF PLANT GROWTH PROMOTING AND BIOLOGICAL CONTROL}

Many reports have evaluated the Pseudomonads as Plant Growth Promoting Rhizobacteria and/or Biological Control Agent $(9,23,86 ; 95,139,149,156)$. Experiments carried out in laboratory, growth chamber and field condition checked the efficiency of these microorganisms $(31,40,88,96,88)$. Plant Growth Promoting Rhizobacteria (PGPR) can stimulate plant growth directly as they can improve the supply of nutrients, such as nitrogen and phosphorous $(27,66,83)$ or by production of phytohormones (85). Indirectly, PGPR can also promote plant development by the suppression of pathogens mediated by different mechanisms $(27,52,162)$.

Many reports show different PGPR species that have the mechanism of directly improving plant development $(66,114)$. Strains of fluorescent Pseudomonas spp. and Bacillus spp. were able to stimulate plant growth by different traits like nitrogen fixation, phosphate solubilization, production of organic acids and IAA (Indole Acetic Acid) (114). Several researchers have selected strains of Bacillus, Azotobacter, Azospirillum and Pseudomonas that produces gibberellin - like substances in culture and reported that they are important to plant growth responses $(56,146)$. Eklund (36) concluded that gibberellin-like substances and other growth-promoting compounds were produced by Pseudomonas spp. Growth stimulation of cucumber was observed following seed inoculation with these strains (36). The positive effects of PGPR on plant growth are always correlated with remarkable changes in root morphology $(13,92,108)$. It is generally assumed that these developmental responses are stimulated by phytohormones produced by the bacteria (14). Among the plant growth regulators, auxin may play a major role supported by the fact that a screen for Arabidopsis thaliana mutants insensitive to Pseudomonas rhizobacteria resulted in the isolation of two mutants altered in the Aux 1 auxin influx transporter (120). But it is necessary to know that the auxin effect depends on the concentration. Inoculation with increasing doses of Pseudomonas strains had positive result to a certain concentration above which it was observed deleterious effects (121).

The suppression of soil-borne plant pathogens is an important indirect mechanism for plant development. The suppression of deleterious populations in the rhizosphere occurs at several forms. Competition for nutrients supplied by roots and seeds and occupation of sites favored for colonization (niche exclusion) probably are responsible for a certain degree of disease suppression by most PGPR and are of primary importance in some strains. Paulitz (119) reported that the biological control of Pythium damping-off by P. putida N1R, applied to the soybean and pea seeds, was mediated by the ability of selected strains to predominate on roots growing from inoculated seed pieces or seed. Although, it is not the only standard used for defining successful PGPR strains. Chin-AWoeng et al (26) observed that the colonization ability of certain PGPR is related to the mechanism involved in the biocontrol action. Antibiosis mechanism requires a convenient colonization of the involved strain(s), while for Induced Resistance mechanism, a lesser number of cells during a limited period, may be sufficient to obtain a successful response in the host plant.

Systemic Acquired Resistance (SAR) is induced when plant activates its defense mechanism in response to the pathogen primary infection during plant-pathogen interactions $(154,160)$. Induction can occur through biotic factors (e.g. infecting or feeding pathogens) or through chemical agents (e.g. salicylate). Induced Systemic Resistance (ISR) is a defense response to the local presence and activity of a variety of biotic and abiotic agents by plants (91). PGPR elicit defensive response by the plant to the pathogen presence. It causes the production of specific substances. Van Peer et al. (155) showed that bacterization of carnation roots with $P$. fluorescens WCS417 reduced significantly the wilting caused by Fusarium oxysporium f. sp. dianthi. Upon pathogen infection, higher amounts of the anthranilate derived phytoalexins dianthalexin (2-phenyl - 7 - hydroxy - 1,3 - benzoxazin - $4 \mathrm{H}$ - one) and a group of diantramides accumulated in plants that had received a root pretreatment with strain WCS417 than in untreated control plants. ISR has been shown to occur in radish, tobacco, common bean, cucumber $(72,73,110,169)$.

Production of metabolites such as, hydrogen cyanides, siderophores, extracellular lytic enzymes and antibiotics is the primary mechanism of biocontrol $(85,103,105,111)$. Production of hydrogen cyanides is a major factor in the antagonism of $P$. fluorescens $\mathrm{CHAO}$ against soil-borne tobacco pathogen Thielaviopsis basicola and has been proposed to act directly on pathogen without damaging the plant (158). Synthesis of $\mathrm{HCN}$ is induced by high ferric iron concentrations whereas 
conditions of low iron are inhibitory (160). Many soils Pseudomonads secrete molecules designated siderophores that bind ferric iron with high affinity. These yellow-green fluorescent siderophores are hydroxamate or phenolate groups and are classified as pyoverdines or pseudobactins (133). Iron competition, mediated by siderophores, is important for biological control (79). Production of siderophores is the main mechanism by which $P$. putida WCS358 controls Fusarium pathogenesis in carnation and radish (160). Biosurfactants are another group of secondary metabolites produced by some Pseudomonas spp. Biosurfactants are polimeres of low molecular weight that reduce the surface and interfacial tensions and polimeres of high molecular weight that bind to the surfaces (135). Some of these compounds have antimicrobial activity, like rhamnolipides (RHLs) and peptide biosurfactants. The RHLs showed activity against zoospores of oomycetes. They caused the imotility and lise of zoospores in less than one minute (145). One strain of $P$. aeruginosa produced RHL B that inhibited the germination of spores of Phytophora capsici e Colletotrichum orbicularie in vitro (63). The Pseudomonas produces some lipopeptide surfactants that are able to inhibit microbial growth. Viscisamide and tensine produced by strains of soil Pseudomonas inhibited micelial growth of some fungi $(106,152)$.

Soils can be microbiologically characterized as conductive and suppressive soils. Conductive soils are described as soils in which plant phytopathogens are detected. Suppressive soils are defined as soils in which the pathogen does not establish or persist; it establishes but causes little or no damage, or the pathogen establishes and causes disease for a while but thereafter the disease is less important, although it may persist in the soil (29). Suppressive soils have been described for a variety of plant pathogens $(29,54)$. Lemanceau and Alabouvette (75) reported that the mechanism of suppression to Fusarium wilt has been related to the activity of microorganisms such as fluorescent Pseudomonads competing with the pathogen. There are numerous reports of antibiotic produced by Pseudomonas spp. Howell and Stipanovic (55) isolated the antibiotic pyrrolnitrin from cultures a strain of $P$. fluorescens that inhibited growth of Rhizoctonia solani, T. basicola, Alternaria sp. and Verticillium dahliae "in vitro". Cotton seedling survival increased from 30 to $79 \%$ when planted into $R$. solani-infested soil by pre-plant treatment of seeds with the strain of $P$. fluorescens or pyrrolnitrin. A year later, the same author isolated another antibiotic, pyoluteorin, produced by another strain of $P$. fluorescens. This antibiotic was inhibitory to Pythium ultimum and reduced seedling disease. Unlike pyrrolnitrin, which persisted actively in soil about 30 days, pyoluteorin was quickly absorbed and inactivated by soil colloids. Weller and Cook (163) reported that two strains isolated from wheat roots, growing in suppressive soils to take-all caused by Gaeumannomyces graminis var. tritici, significantly reduced disease when introduced as seed treatment. They indicated that the antibiotics produced by the strains were responsible for that reduction. Furthers reports concluded that phenazines and phloroglucinols inhibited the pathogen in vitro and in situ $(130,151)$. Many reports showed the efficiency of these antibiotics to control certain plant diseases $(8,32,34,128,132)$. Recently, Kaur et al. (62) suggested that $\mathrm{D}$-gluconic acid was the most significant antifungal agent produced by Pseudomonas spp. strain AN5 in biocontrol of take-all on wheat roots. It indicates that diverse compounds can be associated to the disease suppression and it is necessary continuos investigation to detect them.

Phenazine production was associated to the "Sudden Death Syndrome" (SDS) caused by Fusarium solani, in soybean (17). The major part of the Pseudomonas isolates from soybean crop area without incidence of SDS, produced PCA, Phenazine-1Carboxilic Acid. The isolates were able to inhibiting Fusarium solani growth in vitro.

Bacterial species utilize complex communication mechanisms called quorum-sensing (QS) that link cell density with gene expression $(61,138)$. Diffusible signal molecules denominated autoinducers like acyl-homoserine lactones, accumulate in the extracellular environment, reach a critical threshold concentration and activate the response which leads to gene expression. At threshold cell-density level, bacteria produce substances that inhibit proliferation of pathogens; beneficial bacteria responsible for nitrogen fixation on the other hand, use QS to optimize nodule formation on plant roots. Further advances and better understanding of QS in the rhizosphere will facilitate exploitation of bioinoculants in soil health, plant productivity, bioremediation strategies to environmental applications (138). Plant-associated Pseudomonads utilize quorum-sensing systems to regulate some features that could affect their persistence and viability in plant surfaces $(37,78)$.

The production of the phenazine compounds, as well as, secondary metabolites is regulated by quorum sensing (QS) systems (26). This is observed to P. aureofaciens strain 30-84, effective against take-all, in which there are two separate QS systems that regulate the production of antibiotics and secondary metabolites, exoproteases activity and cell surface features (168). The regulation of phenazine production is linked to the genes $p h z R$ and $p h z I$ members of luxI/luxR gene group and is located upstream of the phenazine operon $(93,166)$. PhzR is a transcriptional activator of phenazine gene expression that functions in response to the cell density-dependent accumulation of a diffusible, acylated homoserine lactone (AHSL) auto-inducer, synthesis of which requires phzI (148). A $p h z R$ mutant of 30-84 did not produce phenazines but was complemented by a wild type plasmid-borne phzR can function in trans to activate phenazine gene expression. Evidence for a diffusible auto-inducer resulted from the observation that cellfree supernatant of 30-84 wild-type or E. coli expressing the 30$84 \mathrm{phzI}$ gene, produced premature expression of biosynthetic 
genes (166). In others analysis AHSL role in the rhizosphere, a phzI defective population of strain 30-84 was restored to wildtype levels of phenazine expression when a population expressing $p h z I$ was present (148). These results showed that AHSL activate phenazine expression and raised the hypothesis that signals produced by heterologous rhizosphere strains could influence the timing or level of phenazine synthesis of the antibiotic producing PGPR in situ $(125,126,148)$.

The presence of a positive autoregulatory loop or quorumsensing systems, such as luxI/luxR families, seemed to be appropriate in environments like rhizosphere where nutrient avaliability is transitory. When populations are small or substrate is limiting, AHSL concentrations would remain below the level required inducing antibiotic gene expression, conserving resources for growth and maintenance. If the nutrient availability increases, and consequently there is increase in the populations, AHSL concentrations could reach the level and carbon and energy used to antibiotic production. Evidence for a QS system in strain 30-84 came from the observation that $p h z R$ gene in trans to a chromosomal $p h z R:: l a c Z$ fusion resulted in a 3.5- fold promotion in $\beta$-galactosidase production $(124,126)$.

The continuous analysis of strains important to biological control are indicating that biosynthesis of antifungal secondary metabolites in Pseudomonas spp. is commonly controlled by a two-component system comprising the sensor kinase GacS and the response regulator GacA. $g a c S$ is the new designation for a group of conserved genes in Pseudomonas spp. that encode functionally homologous cognate sensor kinases (e.g., apdA, lemA, pheN, and repA) (64). In P. fluorescens $\mathrm{CHAO}$, this system tightly controls the expression of several biocontrol factors, such as Phl, HCN, pyoluteorin $(52,53)$. A bacterial signal that was not yet identified, triggers autophosphorilation of the GacS sensor. The phosphate group is transferred to the response regulator GacAby a phospho-relay mechanism (52), Three genes that encode the small non-coding RNAs RsmX, RsmY and Rsm $\mathrm{Z}$ are expressed. Each three RNAs specifically binds two small proteins, RsmA and RsmE. In P. fluorescens, these proteins function as post-transcriptional represssors of typical biocontrol genes by intefering with the function of ribosome-binding site $(52,134)$.

\section{COMMERCIAL USE OF PGPR IN AGRICULTURE}

Nowadays, many trading products for plant disease control are based on BCAs (Table 1). Commercial development of this agricultural product must follow several criteria: large application on major crops, quality control, chemical effects and inoculum formulation (20). Product safety, production costs, effectiveness against target organisms and acreage and value of crops to be treated must all be considered in the development of biological control and PGPR. Microorganisms should be considered for scale-up and commercial use, even where the disease or nematode problem solved may be specific to a relatively small geographic area, a single crop or cropping system, or a few users such as certain growers, processors, or communities (28).

In California and Idaho, PGPR have been effective in increasing yields of potato, sugar beet and radish (20). However, it will be necessary to test strains in other potato growing regions to determine their versatility. It has been discussed the many factors that may affect rhizosphere microbial communities and it is likely different soils, varieties, climatic conditions, etc. will have effect on PGPR performance. Strategies like, use of mixtures of strains (123) and use fertilizer sprays, like urea, that can improve rhizosphere colonization (97) can help to overcome some problems and make preparations more competitive in a variety of growing regions.

In addition to physical, environmental, microbial and variety factors that may affect PGPR, other characteristics must be examined before large-scale commercial production will be practical. Strains of Pseudomonas spp. can mutate in culture and generally lose viability when stored for a period of several weeks (52). Any mutation or lacking of viability may greatly affect performance and could be a catastrophic occurrence for the company selling the product. Efficient quality control will be definitely essential. Reliable assays to check the efficacy of the strains will be necessary. Methods for monitoring inoculant quality are being developed. Duffy and Défago (35) elaborated a method based on the distinctive appearance of GacS/GacA system mutants. Mutation blocks the biosynthesis of antimicrobial compounds in strain P. fluorescens CHAO. They were able to control mutants and clean contaminated cultures using certain minerals, like zinc, copper, manganese or diluting the media.

The identification of factors that control the fate and performance of the inoculants, small-scale analyses are needed due to the heterogeneity characterizing the complex soil and rhizosphere environments $(141,142)$. Direct staining techniques and advanced microscopy had provided the first detailed singlecell images of root colonization by these bacteria using fluorescent antibodies, fluorescent in situ hybridization and marker gene technology. Fluorescence-labeled antibodies have been used with success for detection of root-colonizing Pseudomonas strains by immunofluorescence microscopy $(68,153)$. The rRNAtargeted fluorescent in situ hybridization (FISH) technique offers the possibility of non-extractive detection of target bacteria. Hence, fluorescence-labelled oligonucleotide probes, constructed on the basis of $16 \mathrm{~S}$ rRNA sequence information, hybridize to specific sequences in the ribosomal RNA of fixed and permeabilized target cells (3). Nevertheless, very few cases does rRNA-targeting oligonucleotide sequences provide a specificity compatible with detection of a specific Pseudomonas strain (19). However, using a dual staining technique where immunofluorescence labelling differentiates a specific Pseudomonas strain, the FISH technique appear to be suitable 
Botelho, G.R. and Mendonça-Hagler, L.C.

Table 1. Examples of bacteria formulated as products used as Biological Control Agents.

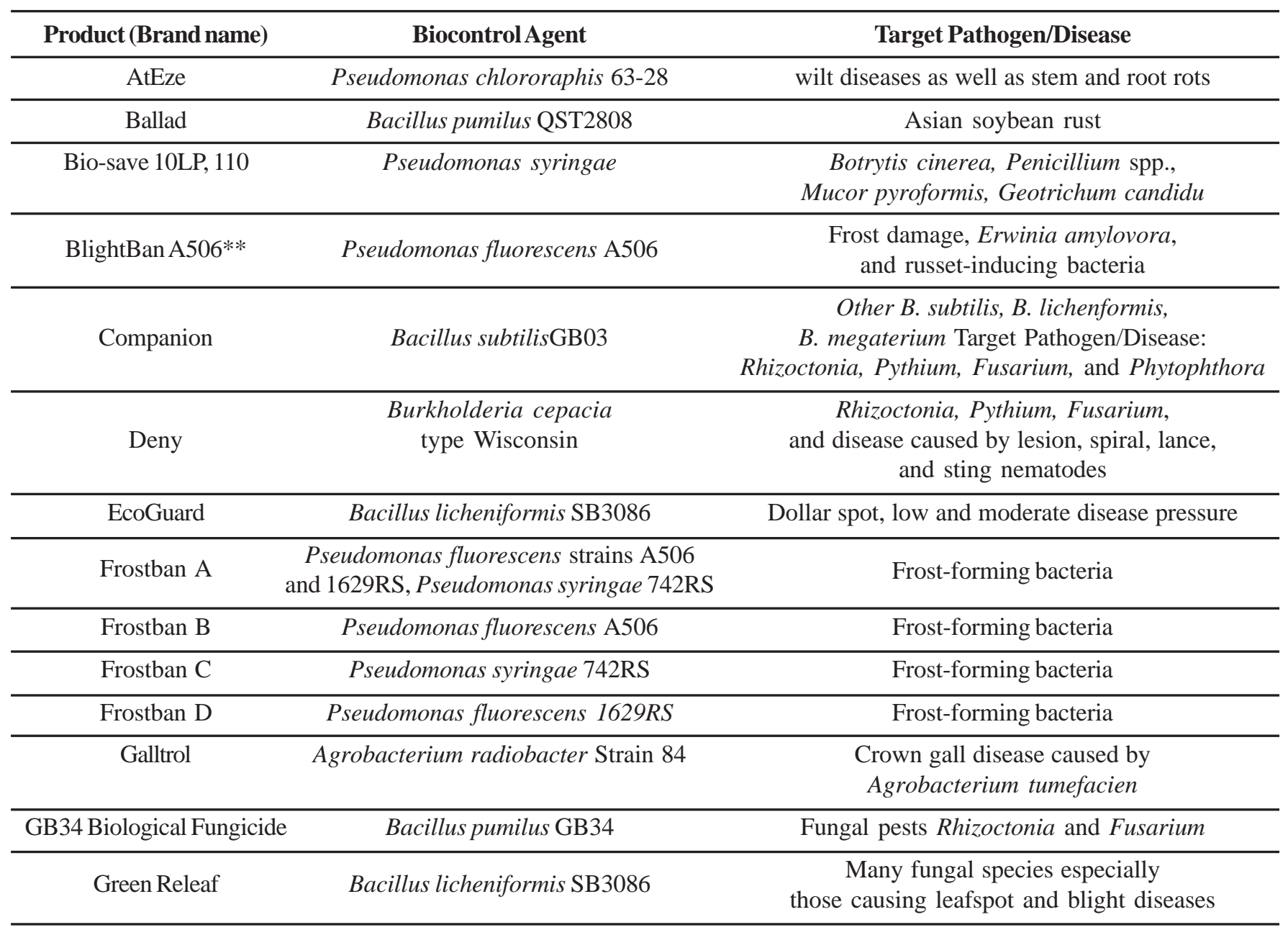

Source: APS Biological Control Committee - http://www.oardc.ohio-state.edu/apsbcc/

for discrimination between levels of the growth activity in inoculant Pseudomonas populations in rhizosphere (82). Another problem is the autofluorescence from soil particles and that can mask the specific fluorescence signal emitted by the tagged cells. Therefore, more detailed in situ studies of single-cell distribution of Pseudomonas inoculants, using immunochemical methods and/ or FISH have only been possible with the advent of confocal laser scanning microscopy (CLSM) (82). Insertion of marker or report genes has been commonly used to distinguish the introduced Pseudomonads from indigenous populations $(45,141)$. Some of the most popular genes used as markers or reporters

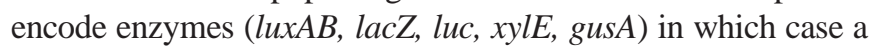
product of the reaction catalyzed by the marker gene is monitored (bioluminescence, color, etc.) (141). Gene product can also be detected by immunochemical techniques. Specific physical properties of the gene products may mediate their detection. It occurs to the product of $g f p$ gene that is a protein, which emits green fluorescence when excited (24).

Another important point to be considered is the pesticide use in the cropping systems. Apparently the majority of fungicides do not affect PGPR. Fungicides used on potato seed pieces, like benomyl, captan, PCNB did not affect PGPR strains but mancozeb was inhibitory using in vitro tests (21). Pseudomonas spp. have a biochemical machinery that confers many possibilities to degrade many compounds $(67,143)$. However, further testing will be necessary as new strains are found and new crops with various chemical needs are tested.

Initially, bacterization of seeds utilized bacterial growth from culture media suspended in water. Although growth responses were noted in some cases, the problems with this system on a large scale are apparent. Strains may soon die in water suspensions and unless planting are done immediately after 
treatment, the inoculum dries and the populations of PGPR decline (21). Powered formulations of PGPR have been developed and a number of commercially available gums were tested as suitable substrates for PGPR in comparison to methylcellulose. It was observed that PGPR establishment on roots and stimulation growth depends on the carrier. There is variability between crops that will be encountered when attempting to develop formulations for wide usage. Suslow and Schroth (147) showed methylcellulose powder formulations were most suitable for pelleting onto sugar-beet. Powered formulations have benefit as the ease of storage, transport and handling. Also, by pelleting seed with a powder formulation is possible to concentrate a higher population of PGPR around the seed than by dipping in bacterial suspensions. The powder formulations also allow for storage for prolonged periods of time until planting. It is necessary more studies to determine most efficient forms to apply PGPR to the plants.

\section{CONCLUDING REMARKS}

The use of fluorescent Pseudomonads as PGPR and/or Biological Control Agents (BCA) requires the precise understanding of the interactions between plant-bacteria, among bacteria - microbiota and how biotic and abiotic factor influence in this relationship. In a few years, modern technologies, such as immunofluorescence microscopy and reporter genes, have improved the study of Pseudomonas inoculants in soil and have markedly enhanced the knowledge about their behavior in this environment $(45,141)$. Nevertheless it is necessary to better understand the plant response to the presence of these introduced bacteria (eg. presence in the high concentration, as in the inoculants). An important consideration is the characterization of the rhizosphere populations. Comprehension of the dynamics of the microbial populations could shed light in the process to select successful strains promoting plant growth and/or suppressing diseases. Recent advances in studies of the intraspecies and interspecies signaling are providing an important area for scientific research, as well as, relevant application. Understanding quorum sensing systems in antifugal metabolite production and identification of promoters that can be induced or increased in the rhizosphere give new approaches for the development of new biological control agents $(136,159)$.

Another important concern is the impact of microorganism massive introduction can cause to the soil ecosystem. It is important to evaluate the possible impact on the native communities and the resulting effects. Many studies had analyzed the impact and the survival and ability to compete of these microorganisms. Botelho et al. (18) observed no difference in the size, structure and function of bacteria communities analyzed when a strain of $P$. fluorescens was introduced by seeds of maize. Guimarães et al. $(47,48)$ and Araújo et al. $(4,5,6)$ observed that a strain of $P$. fluorescens and its OGM were able to survival and/or colonize bulk soil and rhizosphere of maize. Moënne-Loccoz et al. (100) results suggested that the root-associated Pseudomonas community of sugar beet seedlings was resilient to the impact that may be caused by a taxonomically related inoculant. Nevertheless, the response of introduction of microorganisms will vary due to a plethora of factors that should be checked before considering their use as a BCA.

Many strategies to achieve the control of plant diseases using microorganisms as biological control agents (BCAs) have produced significant success. Recently, Ji et al. (59) tested a combined use of foliar biological control agents and PGPR. The foliar biocontrol agent (P. syringae strain Cit7) and PGPR ( $P$. fluorescens strain 89B-61) provided significant control of bacterial speck and spot of tomato in field trials. These agronomic strategies are relevant since one of the goals of using PGPR/ BCAs, is to make them trustable and assessable product to the farmers. Consequently, continuos searching for new approaches to improve the efficiency of PGPR/BCAs are tightly linked to understand the ecological, genetic and biochemical relationships in their habitat. This is a strategy to achieve a sustainable agriculture in the world.

\section{RESUMO}

\section{Pseudomonas spp. associadas à rizosfera de plantas de uso agrícola - um panorama}

As preocupações com o meio ambiente têm levado à necessidade do uso sustentável dos recursos naturais. A agricultura convencional tem causado impactos consideráveis no solo e nas águas. É importante mudar certas técnicas agrícolas por outras consideradas mais limpas para o meio ambiente. Uma estratégia é a utilização da microbiota do solo para induzir o crescimento de plantas, controlar fitomoléstias e para fazer a biodegradação de compostos xenobióticos. Estudos sobre a relação entre as raízes e a microbiota são essenciais para conseguir aplicações viáveis na agricultura. Estes estudos têm indicado que um dos mais abundantes microrganismos na rizosfera (região ao redor da raiz) é Pseudomonas spp. do grupo fluorescente. Estes têm sido considerados como alternativa tanto aos agrotóxicos no controle de doença de plantas como na indução do seu desenvolvimento. Esta revisão mostra os principais conhecimentos sobre Pseudomonas spp. do grupo fluorescente. Esta resume e discute aspectos significantes deste tópico, incluindo, (i) rizosfera como microhabitat; (ii) aspectos taxonômicos, genéticos e ecológicos de Pseudomonas spp. do grupo das fluorescentes na rizosfera; (iii) mecanismos de Promoção de Crescimento de Plantas e Controle Biológico e (iv) uso comercial de PGPR na agricultura.

Palavras-chave: promoção de crescimento vegetal, controle biológico, Pseudomonas fluorescente, rizosfera 


\section{REFERENCES}

1. Alexander, M. Ecological interrelationships: Microbiology of rhizosphere. In:____eds). Soil microbiology. Wiley Eastern Limited, Nova York, 1977, p.423-437.

2. Alström, S. Induction of disease resistance in common bean susceptible to halo blight bacterial pathogen after seed bacterisation with rhizosphere pseudomonads. J. Gen. Appl. Microbiol., 37, 495-501, 1991.

3. Amann, R.I.; Ludwig, W.; Schleifer, K. Phylogenetic identification and in situ detection of individual microbial cells without cultivation. Microbiol. Rev., 59, 143-169, 1995.

4. Araújo, M.A.V.; Mendonça-Hagler, L.C.; Hagler, A.N.; Van Elsas, J.D. Survival of genetically modified Pseudomonas fluorescens introduced into subtropical soil microcosms. FEMS Microbiology Ecology, 13(3), 205-216, 1994.

5. Araújo, M.A.; Mendonça-Hagler, L.C.; Hagler, A.N.; van Elsas, J.D. Competition between a genetically modified Pseudomonas fluorescens and its parent in sub-tropical soil microcosms. Rev. Microbiol., (26), 1-15, 1995.

6. Araújo, M.A.; Mendonça-Hagler, L.C.; Hagler, A.N.; van Elsas, J.D. Selection of rhizosphere-competent Pseudomonas strains as biocontrol agents in tropical soils. World J. Microbiol. Biotechnol., (12), 589-593, 1996.

7. Azevedo, J.L.; Maccheroni Júnior, W.; Araújo, W.L.; Pereira, J.O. Microrganismos endofíticos e seu papel em plantas tropicais. In: Serafini, L.A.; Monteiro, N.B. and Azevedo, J.L. (eds). Biotecnologia: avanços na agricultura e na agroindústria. EDUCS - Editora da Universidade de Caxias do Sul, Caxias do Sul, 2002, p.233-268.

8. Bangera, M.G.; Thomashow, L.S. Characterization of a genomic locus required for synthesis of antibiotic 2,4 diacetylphloroglucinol by biological control agent Pseudomonas fluorescens Q2-87. Mol. Plant-Microbe Interaction, 9, 83-90, 1996.

9. Barbosa, M.A.G.; Michereff, S.J.; Mariano, R.L.R.; Maranhão, E. Biocontrole de Rhizoctonia solani em caupi pelo tratamento de sementes com Pseudomonas spp. fluorescens. Grupo Paulista de Fitopatologia, 21(2), 151-157, 1995.

10. Benizri, E.; Courtade, A ; Picard, C.; Guckert, A. Role of maize root exudates in the production of auxins by Pseudomonas fluorescens M.3.1. Soil Biol. Biochem., 30(10), 1481-1484, 1998.

11. Berg, G.; Krechel, A.; Ditz, M.; Sikora, R.A.; Ulrich, A.; Hallmann, J. Endophytic and ectophytic potato-associated bacterial communities differ in structure and antagonistic function against plant pathogenic fungi. FEMS Microbiology Ecology, 51, 215-229, 2005.

12. Bergsma-Vlami, M.; Prins, M.E.; Raaijmakers, J. M. Influence of plant species on population dynamics, genotypic diversity and antibiotic production in the rhizosphere by indigenous Pseudomonas spp. FEMS Microbiol. Ecol., 52, 59-69, 2005.

13. Bertrand, H.; Nalin, R.; Bally, R.; Cleyet-Marel, J.C. Isolation and identification of the most efficient plant growth-promoting bacteria associated with canola (Brassica napus). Biol. Fertil. Soils, 33,152156, 2001.

14. Bloemberg, G.V.; Lugtenberg, B.J.J. Molecular basis of plant growth promotion and biocontrol by rhizobia. Curr. Opin. Plant Biol., 4, 343-350, 2001.

15. Bossis, E.; Lemanceau, P.; Latour, X.; Gardan, L. The taxonomy of Pseudomonas fluorescens and Pseudomonas putida: current status and need for revision. Agronomie, 20, 51-63, 2000.

16. Botelho, G.R.; Neves, M.C.P.; Xavier, G.R.; Rumjanek, N.G. Uso de ITS ("Intergenic Transcribed Spacer") para caracterização genotípica de isolados de Pseudomonas do grupo fluorescente para uso no controle biológico. Seropédica - RJ. 2005. 7p. (Embrapa Agrobiologia. Comunicado Técnico, 80).

17. Botelho, G.R. Seleção de Pseudomonas fluorescentes para Controle Biológico da Podridão Vermelha da Raiz causada por Fusarium solani. Rio de Janeiro, 2001, 108p. (Dr. Thesis, Biotecnologia Vegetal, UFRJ).

18. Botelho, G.R.; Guimarães, V.; De Bonis; Fonseca, M.E.F.; Hagler, A.N.; Hagler, L.C.M. Ecology of a plant growth-promoting strain of Pseudomonas fluorescens colonizing the maize endorhizosphere in tropical soil. World J. Microbiol. Biotechnol., 14, 499- 504, 1998.

19. Boye, M.; Ahl, T.; Molin, S. Application of a strain-specific rRNA oligonucleotide probe targeting Pseudomonas fluorescens $\mathrm{Ag} 1$ in a mesocosm study of bacterial release into the environment. Appl. Environ. Microbiol., 61,1384-1390, 1995.

20. Burr, T.J.; Caesar, A. Beneficial plant bacteria. Crit. Rev. Plant Sci., 2, 1-20, 1984.

21. Burr, T.J.; Schroth, M.N.; Suslow, T. Increased potato yield on treatment of seed pieces with specific strains of Pseudomonas fluorescens and P. putida. Phytopathology, 68, 1377-1383, 1978.

22. Campbell, R.; Greaves, M.P. Anatomy and community structure of the rhizosphere. In: Lynch, J.M. (eds). The rhizosphere. John Wiley \& Sons Ltd., Chichester, 1990, p.11-34.

23. Cattelan, A.J. Antagonismo de Pseudomonas do Grupo Fluorescente A Fungos Fitopatogênicos de Solo e de Sementes de Soja. Rev. Bras. Ciênc. Solo, 18(1), 37-42, 1994.

24. Chalfie, M.; Tu, Y.; Euskirchen, G.; Ward, W.W.; Prasher, D.C. Green fluorescent protein as a marker for gene expression. Science, 263, 802-805, 1994

25. Champion, A.B.; Barrett, E.L.; Palleroni, N.J. Evolution in Pseudomonas fluorescens. J. Gen. Microbiol., 120, 485-511, 1980.

26. Chin-A-Woeng, T.F.C.; Bloemberg, G.V.; Lugtenberg, J.J. Phenazines and their role in biocontrol by Pseudomonas bacteria. New phytologist, 157, 503-523, 2003.

27. Compant, S.; Duffy, B.; Nowak, J.; Clément, C.; Barka, E.A. Use of plant growth-promoting bacteria for biocontrol of plant diseases: principles, mechanisms of action, and future prospects. Appl. Environ. Microbiol., 71(9), 4951-4959, 2005.

28. Cook, R.J. Making greater use of introduced microorganisms for biological control of plant pathogens. Ann. Rev. Phytopathol., 31, 53-80, 1993.

29. Cook, R.J.; Baker, K.F. The nature and practice of biological control of plant pathogens. APS Press, St. Paul, 1989, 539p.

30. De Bruijn, F.J.; Schneider, M.; Rossbach, U.; Louws, F.J. Automated fluorescent and conventional Rep-PCR genomic fingerprinting and multiplex PCR to classify bacteria and track genes. In: Martins, M.T.; Sato, M.I.Z.; Tiedje, J.M.; Hagler, L.C.N.; Döbereiner, J.; Sanchez, P.S. (eds). Progress in Microbial Ecology. SBM, São Paulo, 1997, p.197-205.

31. De Freitas, J.R.; Germida, J.J. Plant growth promoting rhizobacteria for winter wheat. Can. J. Microbiol., 36, 265-272, 1989.

32. Défago, G. 2,4- diacetylphloroglucinol, a promising compound in biocontrol. Plant Pathol, 42, 311-312, 1993.

33. Delorme, S.; Philippot, L.; Edel-Hermann, V.; Deulvot, C.; Mougel, C.; Lemanceau, P. Comparative genetic diversity of narG, narZ, and 16S rRNA genes in fluorescent Pseudomonads. Appl. Environ. Microbiol., 69(2), 1004-1012, 2003.

34. De Souza, J.T. Distribution, diversity and acticity of antibioticproducing Pseudomonas spp. Wageningen -Holanda, 2002, 161p. (PhD. Thesis. Universidade de Wageningen).

35. Duffy, B.K.; Défago, G. Controlling instability in gacs-gaca regulatory genes during inoculant production of Pseudomonas fluorescens biocontrol strains. Appl. Environ. Microbiol., 66(8), 3142-3150, 2000.

36. Eklund, E. Secondary effects of some pseudomonads in the rhizoplane of peat grown cucumber plants. Acta Agric. Scand. Suppl., 17, 1-57, 1970.

37. Fonseca, M.C.C.; Rumjanek, N.G.; Xavier, G.R. "Quorum sensing": uma nova interpetação da incidência e controle de doenças de plantas. Seropédica: Embrapa Agrobiologia, 2004.37p. (Embrapa Agrobiologia. Documentos, 170). 
38. Fonseca, M.C.C. Diversidade de Pseudomonas spp. fluorescentes no Sistema Integrado de Produção Agroecológica (SIPA), Seropédica RJ, 2003. 136p. (PhD. Thesis. Universidade Federal Rural do Rio de Janeiro).

39. Fonseca, M.C.C.; Zago, V.C.P.; De-Polli, H.; Rumjanek, N. Levantamento e caracterização morfológica de isolados de Pseudomonas spp. fluorescentes presentes em cultivo do SIPA Sistema Integrado de Produção agroecológica. Seropédica - RJ. 2001. 35p. Embrapa Agrobiologia Documentos, 143.

40. Freitas, S.S. Desenvolvimento de plântulas de café pela inoculação de Pseudomonas sp. Rev. Bras. Cienc. Solo, 13, 31-34, 1989.

41. Gamalero, E.; Trotta, A.; Massa, N.; Copetta, A.; Martinotti, M.G.; Berta, G. Impact of two fluorescent pseudomonads and an arbuscular mycorrhizal fungus on tomato plant growth, root architecture and $\mathrm{P}$ acquisition. Mycorrhiza, 14(3), 185-192, 2004.

42. García-Martínez, J.; Acinas, S.G.; Antón, A.I.; Rodríguez-Valera, F. Use of 16-23S ribosomal genes spacer region in studies of prokaryotic diversity. J. Microbiol. Meth., 36, 55-64, 1999.

43. Godfrey, S.A.C.; Marshall, J.W. Soil on imported shipping containers provides a source of new Pseudomonad biodiversity into New Zealand. New Zealand J. Crop Hortic. Sci., 30, 19-27, 2002.

44. Gomes, N.C.M.; Heuer, H.; Schönfeld, J.; Costa, R.; MendonçaHagler, L.; Smalla, K. Bacterial diversity of the rhizosphere of maize (Zea mays) grown in tropical soil studied by temperature gradient gel electrophoresis. Plant and Soil, 232, 167-180, 2001.

45. Götz, M.; Gomes, N.C.M.; Dratwinski, A.; Costa, R.; Berg G.; Peixoto, R.; Mendonça-Hagler, L.; Smalla, K. Survival of $g f p$-tagged antagonistic bacteria in the rhizosphere of tomato plants and their effects on the indigenous bacterial community. FEMS Microbiol Ecol., 56, 207-218, 2006.

46. Grimont, P.A.D.; Vancanneyt, M.; Lefèvre, M.; Vandemeulebroecke, K.; Vauterin, L.; Brosch, R.; Kersters, K.; Grimont, F. Ability of Biolog and Biotype 100 systems to reveal the taxonomic diversity of the Pseudomonads. Syst. Appl. Microbiol., 19, 510-527, 1996.

47. Guimarães, V.F.; Rodrigues, P.M.; Hagler, A.N. Mendonça-Hagler, L.C.; Van Elsas, J.D. Starvation-induced stress cross-protection development in a genetically modified Pseudomonas fluorescens strain. Rev. Microbiol., 28, 245-251, 1997a.

48. Guimarães, V.F.; Cruz, I.V.; Hagler, A.N.; Mendonça-Hagler, L.C.; Van Elsas, J.D. The vertical transport of a genetically modified Pseudomonas fluorescens and its parent strain through undisturbed tropical soil core microcosms. Appl. Soil Ecol., 7, 41-50. 1997b.

49. Gutell, R.R.; Weiser, B.; Woese, C.R.; Noller, H.F. Compartive anatomy of 16S-like ribosomal RNA. Prog. Nucleic. Acid Res. Mol. Biol., 32, 155-216, 1985.

50. Gürtler, V.; Stanisich, V.A. New approaches to typing and identification of bacteria using the 16S - 23S rDNA spacer. Microbiology, 142, 3-16, 1996.

51. Holt, J.G.; Krieg, N.R.; Sneath, P.H.A.; Staley, J.T.; Williams, S.T. Genus Pseudomonas. In: Holt, J.G.; Krieg, N.R.; Sneath, P.H.A; Staley, J.T.; Williams, S.T. (eds) Bergey's manual of determinative bacteriology, Williams \& Wilkins, 1994, p. 93-94.

52. Haas, D.; Défago, G. Biological control of soil-borne pathogens by fluorescent pseudomonads. Nature Rev. Microbiol., 3(4), 307-319, 2005 .

53. Haas, D.; Keel, C. Regulation of antibiotic production in rootcolonizing Pseudomonas spp. and relevance for biological control of plant disease. Annu. Rev. Phytopathol., 41, 117-153, 2003.

54. Hornby, D. Suppressive soils. Аnпи. Rev. Phytopathol., 21, 65-85, 1983.

55. Howell, C.R.; Stipanovic, R.D. Control of Rhizoctonia solani on cotton seedlings with Pseudomonas fluorescens and with an antibiotic produced by the bacterium. Phytopayhology, 69, 480-482, 1979.

56. Hussain, A.; Vancura, V. Formation of biologically active substances by rhizosphere bacteria and their effect on plant growth. Folia Microbiol., 15, 468-478, 1970.
57. Janse, J.D.; Derks, J.H.J.; Spit, B.E.; Van Der Tuin, W.R. Classification of fluorescent soft rot Pseudomonas bacteria, including P. marginalis strains, using whole cell fatty acid analysis, Syst. Appl. Microbiol., 15, $538-553,1992$.

58. Jensen, M.A.; Webster, J.A.; Straus, N. Rapid identification of bacterial on the basis of polymerase chain reaction amplified ribosomal DNA spacer polymorphisms. Appl. Environ. Microbiol., 59(4), 945952, 1993.

59. Ji, P.; Campbell, H.L.; Kloepper. J.W.; Jones, J.B.; Suslow, T.V.; Wilson, M. Integrated biological control of bacterial speck and spot of tomato under field conditions using foliar biological control agents and plant growth-promoting rhizobacteria. Biol. Control., 36(3), 358-367, 2006.

60. Jonhson, J.; Palleroni, N.J. Desoxyribonucleic acid similarities among Pseudomonas species. Int. J. Syst. Bacteriol., 39, 230-235, 1989.

61. Keller, L.; Surette, M.G. Communication in bacteria: an ecological and evolutionary perspective. Nature Rev. Microbiol., 4, 249-258, 2006

62. Kaur, R.; Macleod, J.; Foley W.; Nayudu, M. Gluconic acid: an antifungal agent produced by Pseudomonas species in biological control of take-all. Phytochemistry, 67(6), 595-604, 2006.

63. Kim, B.S.; Lee, J.Y.; Hwang, B.K. In vivo control and in vitro antifungal activity of rhamnolipid B., a glycilipid antibiotic, against Phytophthora capsici and Colletotrichum orbiculare. Pest. Manag. Sci., 56, 1029-1035, 2000 .

64. Kitten, T.; Kinscherf, T.G.; McEvoy, J.L.; Willis, D.K. A newly identified regulator is required for virulence and toxin production in Pseudomonas syringae. Mol. Microbiol., 28, 917-929, 1998.

65. Kloepper, J.W.; Schippers, B.; Bakker, P.A.H.M. Proposed elimination of the term endorhizosphere. Phytopathology, 82(7), 726-727, 1992

66. Kole, S.C.; Hajra, J.N. Isolation and evaluation of tricalcium and rock phosphate solubilizing microorganisms from acidic terai and lateritic soils of West Bengal. J. Interacademicia, 1(3), 126-128, 1997.

67. Kononova, S.K.; Nesmeyanova, M.A. Phosphonates and their degradation by microorganisms. Biochemistry (Moscow), 67(2), 184 195, 2002

68. Kragelund, L.; Nybroe, O. Competition between Pseudomonas fluorescens $\mathrm{Ag} 1$ and Alcaligenes eutrophus JMP134 (pJP4) during colonization of barley roots. FEMS Microbiol. Ecol., 20, 41-51, 1996.

69. Kumar, B.S.D.; Berggren, I.; Mårtensson, A.M. Potential for improving pea production by co-inoculation with fluorescent Pseudomonas and Rhizobium. Plant Soil, 229, 25-34, 2001.

70. Landa, B.B.; Mavrodi, O.V.; Raaijmakers, J.M.; Mcspadden-Gardener, B.B.; Thomashow, L.S.; Weller, D.M. Differential ability of genotypes of 2,4- diacetylphloroglucinol-producing Pseudomonas fluorescens strains to colonize the roots of pea plants. Appl. Environ. Microbiol., 68, 3226-3237, 2002.

71. Latour, X.; Corberand, T.; Laguerre, G.; Allard, F.; Lemanceau, P. The composition of fluorescent Pseudomonad populations associated with roots is influenced by plant and soil type. Appl. Environ. Microbiol, 62, 2449-2456, 1996.

72. Laville, J.; Voisard, C.; Keel, C.; Maurhofer, M.; Defago, G.; Keel, C.; Haas, D. Global control in Pseudomonas fluorescens mediating antibiotic synthesis and suppression of black root rot of tobacco. Proc. Natl. Acad. Sci., 89, 1562-1566, 1992.

73. Leeman, M.; Van Pelt, J.A.; Den Ouden F.M.; Heinsbrock M.; Bakker P.A.H.M. \& Schippers B. Induction of systemic resistance against Fusarium wilt of radish by lipopolysaccharides of Pseudomonas fluorescens. Phytopathology, 85, 1021-1027, 1995.

74. Lemanceau, P.; Corberand, T.; Gardan, L.; Latour, X.; Laguerre, G.; Boeufgras, J.M.; Alabouvette, C. Effect of two plant species, flax (Linum Usitatissinum L.) and tomato (Lycopersicon esculentum Mill.), on the diversity of soilborne populations of fluorescent 
pseudomonads. App. Environ. Microbiology, 61(3), 1004-1012, 1995.

75. Lemanceau, P.; Alabouvette, C. Biological control of fusarium diseases by fluorescent Pseudomonas and non-pathogenic Fusarium. Crop Prot., 10, 279-286, 1991.

76. Lifshitz, R.; Kloepper, Q.Q.; Kozlowski, M.; Simonson, C.; Carlson, J.; Tipping, E.M.; Zaleska, I. Growth promoting of canola (rapeseed) seedlings by a strain of Pseudomonas putida under gnotobiotic conditions. Canadian J. Microbiol., 33, 390-395, 1987.

77. Locatelli, L.; Tarnawski, S.; Hamelin, J.; Rossi, P.; Aragno, M.; Fromin, N. Specific PCR amplification for the genus Pseudomonas targeting the $3^{\prime}$ half of $16 \mathrm{~S}$ rDNA and the whole $16 \mathrm{~S}-23 \mathrm{~S}$ rDNA spacer. Syst. Appl. Microbiol., 25, 220-227, 2002.

78. Loh, J.; Pierson, E.; Pierson III, L.S.; Stacey, G.; Chatterjee, A. Quorum sensing in plant-associated bacteria. Curr. Op. Plant Biol., 5(4), 285-290, 2002.

79. Loper, J.E.; Buyer, J.S. Siderophores in microbial interactions on plant surfaces. Mol. Plant-Microbe Interactions, 4, 5-13, 1991.

80. Lottmann, J.; Heuer, H.; De Vries, J.; Mahn, A.; Düring, K.; Wilfried Wackernagel, W.; Smalla, K.; Berg, G. Establishment of introduced antagonistic bacteria in the rhizosphere of transgenic potatoes and their effect on the bacterial community. FEMS Microbiol. Ecol., 33(1), 41-49, 2000.

81. Louws, F.J.; Fullbright, D.W.; Stephens, C.T.; de Bruijn, F.J. Specific genomic fingerprintings of phytopathogenic Xantomonas and Pseudomonas pathovars and strains generated with repetitive sequences and PCR. Appl. Environ. Microbiol., 60, 2286-2295, 1994.

82. Lübeck, P.S.; Hansen, M.; Sørensen, J. Simultaneous detection of the establishment of seed-inoculated Pseudomonas fluorescens strain DR54 and native soil bacteria on sugar beet root surfaces using fluorescence antibody and in situ hybridization technique. FEMS Microbiol. Ecol., 33, 11-19, 2000.

83. Lugtenberg, B.J.J.; Dekkers, L.C. What makes Pseudomonas bacteria rhizosphere competent? Environ. Microbiol., 1, 9-13, 1999.

84. Lugtenberg, B.J.J.; Kravchenko, L.V.; Simons, M: Tomato seed and root exudates sugars: composition, utilization by Pseudomonas biocontrol strains and role in rhizosphere colonization. Environ Microbiol., 1, 439-446. 1999.

85. Lugtenberg, B.J.J.; De Weger, A.L.; Bennet, J.W. Microbial stimulation of plant growth and protection from disease. Curr. Op. Biotechnology, 2, 457-464, 1991.

86. Luna, C.L.; Mariano, R.L.R.; Maior, A.M.S. Production of a Biocontrol agent for Crucifers Black Rot Disease. Braz. J. Chem. Eng., 19(2), 133-140, 2002.

87. Lupski, J.R.; Weinstock. G.M. Short, interspersed repetitive DNA sequences in prokaryotic genomes. J. Bacteriol., 174, 4525-4529, 1992

88. Luz, W.C. Evaluation of plant growth-promoting and bioprotecting rhizobacteria on wheat crop. Fitopatol. Bras., 26(3), 597-600, 2001

89. Lynch, J.M. The rhizosphere. John Wiley \& Sons Ltd., Chichester, 1990, $458 \mathrm{p}$.

90. Mandimba, G.; Heulin, T.; Bally, R.; Guckert, A.; Balandreau, J. Chemotaxis of free-living nitrogen-fixing bacteria towards maize mucilage. Plant Soil, 90, 129-139, 1986.

91. Mariano, R.L.R.; Kloepper, J.W. Método alternativo de biocontrole: resistência sistêmica induzida por bactérias. Revisão anual de patologia de plantas, 8, 121-137, 2000.

92. Mantelin, S.; Touraine, B. Plant growth-promoting bacteria and nitrate availability: impacts on root development and nitrate uptake. J. Exp. Bot., 55(394), 27-34, 2004

93. Mavrodi, D.V.; Ksenzenko, V.N.; Bonsall, R.F.; Cook, R.J.; Boronin, A.M.; Thomashow, L.S. A seven -gene locus for synthesis of phenazine -1 carboxylic acid by Pseudomonas fluorescens 2-79. J. Bacteriol., 180(9), 2541-2548, 1998.
94. Mazzola, M.; Cook, J.; Thomashow, L.S.; Weller, D.M.; Pierson III, L.S. Contribution of phenazine antibiotic biosynthesis to the ecological competence of fluorescent pseudomonads in soil habits. Appl. Environ. Microbiol., 58(8), 2616-2624, 1992.

95. Melo, I.S.; Azevedo, J.L. Controle Biológico. EMBRAPA - Meio Ambiente, Jaguariúna, 2000, v.2, 308p.

96. Mello, M.R.F.; Mariano, R.L.R.; Menezes, M.; Câmara, T.R.; Assis, S.M.P. Seleção de bactérias e métodos de bacterização para promoção de crescimento em mudas de abacaxizeiro micropropagadas. Summa Phytopathol., 28(3), 222-228, 2002.

97. Mendez-Castro, F.A; Alexander, M. Method for establishing a bacterial inoculum on corn roots. Appl. Environ. Microbiol., 45(1), 248-254, 1983.

98. Mirleau, P.; Delorme, S.; Philippot, L.; Meyer, J.M.; Mazurier, S.; Lemanceau, P. Involvement of nitrate redutase and pyoverdine in competitiveness of Pseudomonas fluorescens strain C7R12 in soil. Appl. Environ. Microbiol., 67, 2627-2635, 2001.

99. Misko, A.L.; Germida, J.J. Taxonomic and functional diversity of pseudomonads isolated from the roots of field-grown canola. FEMS Microbiol. Ecol., 42, 399-407, 2002.

100. Moënne-Loccoz, Y.; Tichy, H.V.; O'donnell, A.; Simon, R.; O'gara. Impact of 2,4-Diacetylphloroglucinol-Producing Biocontrol Strain Pseudomonas fluorescens F113 on Intraspecific diversity of resident culturable fluorescent Pseudomonads associated with the roots of field-grown sugar beet seedlings. Appl. Environ. Microbiol., 67(8), 3418-3425, 2001.

101. Moore, E.R.B.; Mau, M.; Arnscheidt, A.; Böttger, E.C.; Hutson, R.A.; Collins, M.D.; Van Der Peer, Y.; De Wachter, R.; Timmis, K.N. The determination and comparison of the $16 \mathrm{~S}$ rRNA gene sequences of species of the genus Pseudomonas (sensu stricto) and estimation of the natural intrageneric reletionships. Syst. Appl. Microbiol., 19, 478 -492, 1996.

102. Montesinos, E.; Bonaterra, A.; Badosa, E.; Frances, J.; Alemany, J.; Llorente I.; C. Moragrega. Plant-microbe interactions and the new biotechnological methods of plant disease control. Int. Microbiol., 5, 169-175, 2002.

103. Nagarajkumar, M.; Bhaskaran, R.; Velazhahan, R. Involvement of secondary metabolites and extracellular lytic enzymes produced by Pseudomonas fluorescens in inhibition of Rhizoctonia solani, the rice sheath blight pathogen. Microbiol. Res., 159, 73-81, 2004.

104. Neefs, J.M.; Van der Peer, Y.; Hendriks, L.; De Wachter, R. Compilation of small ribosomal subunit RNA sequences. Nucleic Acid Res., 18, 2237-2317, 1990.

105. Nicodème, M.; Grill, J.P.; Humbert, G.; Gaillard, J.L. Extracellular protease activity of different Pseudomonas strains: dependence of proteolytic activity on culture conditions. J. Appl. Microbiol., 99, 641-648, 2005

106. Nielsen, T.H.; Thrane, C.; Christeophersen, C.; Anthoni, U.; Sørensen, D.N. Structure, production characteristic and fungal antagonism of tensin - a new antifungal cyclic lipopeptide from Pseudomonas fluorescens 96.578. J. Appl. Microbiol., 89, 992-1001, 2000.

107. Normand, P.; Ponsonnet, C.; Nesme, X.; Neyra, M.; Simonet, P. ITS analysis of prokariotes. In: Akkermans, D.L.; Van Elsas, J.D.; Bruijn, F.J. (eds) Molecular Microbial Ecology Manual. Kluwer Academic Publishers, Dordrecht, 1996, p.1-12.

108. Okon, Y.; Vanderleyden, J. Root-associated Azospirillum species can stimulate plants. ASM News, 63, 366-370, 1997.

109. Oliveira, A.L.M.; Urquiaga, S.; Baldani, J.I. Processos e mecanismos envolvidos na influência de microrganismos sobre o crescimento vegetal. Seropédica: Embrapa Agrobiologia, 2003.40p. (Embrapa Agrobiologia. Documentos, 161).

110. Ongena, M.; Giger, A.; Jacques, P.; Dommes, J.; Thonart, P. Study of bacterial determinants involved in the induction of systemic resistance in bean by Pseudomonas putida BTP1. Eur. J. Plant Pathol., 108, 187-196, 2002. 
111. O’Sullivan, D.; O'Gara, F. Traits of fluorescent Pseudomonas spp. involved in suppression of plant root pathogens. Microbiol. Rev., 56(4), 662-674, 1992.

112. Ownley, B.H.; Duffy, B.K.; Weller, D.M. Identification and manipulation of soil properties to improve the biological control performance of phenazine-producing Pseudomonas fluorescens. Appl. Environ. Microbiol., 69(6), 3333-3343, 2003.

113. Pacheco, C.C.; Passos, J.F.; Moradas-Ferreira P.; De Marco P. Strain PM2, a novel methylotrophic fluorescent Pseudomonas sp. FEMS Microbiol. Lett., 227, 279-285, 2003.

114.Pal, K.K.; Tilak, K.V.B.R.; Saxcna A.K.; Dey R.; Singh, C.S. Suppression of maize root diseases caused by Macrophomina phaseolina, Fusarium moniliforme and Fusarium graminearum by plant growth promoting rhizobacteria. Microbiol. Res., 156(3), 209223, 2001.

115. Palleroni, N.J. Pseudomonas classificassion: a new case history in the taxonomy of gram-negative bacteria. Antonie van Leeuwenhoek, 64, 231-251, 1993.

116. Palleroni, N.J. Genus I Pseudomonas. In: Krieg, N.R.; Holt, J.G.(eds) Bergey's manual of determinative bacteriology. Williams and Wilkins Co Baltimore, 1984, (1), p.141-168.

117. Palleroni, N.J.; Kunisawa, R.; Contopolou, R.; Doudoroff, M. Nucleic acid homologies in the genus Pseudomonas. J. Syst. Bacteriol., 23, 333-339, 1973.

118. Palleroni, N.J.; Ballard, R.W.; Ralston, E.; Doudoroff, M. Deoxyribonucleic acid homologies among some Pseudomonas species, J. Bacteriol., 110, 1-11, 1972.

119. Paulitz, T.C. Effect of pseudomonas putida on stimulation of pythium ultimum by seed volatile of pea and soybean. Phytopathology, 81, 1282-1287, 1991.

120. Persello-Cartieaux, F.; David, P.; Sarrobert, C.; Thibaud, M.C.; Achouak W.; Robaglia C.; Nussaume, L. Utilization of mutants to analyze the interaction between Arabidopsis thaliana and its naturally root-associated Pseudomonas. Planta, 212, 190-198, 2001.

121. Persello-Cartieaux, F.; Nussaume, L.; Robaglia, C. Tales from the underground: molecular plant-rhizobia interactions. Plant, Cell Environ., 26, 189-199, 2003.

122. Picard, C.; Di Cello, F.; Ventura, M.; Fani, R.; Guckert, A. Frequency and biodiversity of 2,4-diacetylphloroglucinol-producing bacteria isolated from the maize rhizosphere at different stage of plant growth. Appl. Environ. Microbiol., 66(3), 948-955, 2000.

123.Pierson, L.S.; Weller, D.M. Use of mixtures of fluorescent pseudomonads to suppress take-all and improve the growth of wheat. Phytopathology, 84, 940-947, 1994.

124. Pierson III, L.S.; Pierson, E.A.; Wood, D.W.; Chancey, S.T.; Harvey, D.E. Recent advances in genetic regulation of activity of plant growth-promoting rhizobacteria. In: Ogoshi, A.; Kobayashi, K.; Homma, F.; Kondo; N.; Akino, S. Plant growth-promoting rhizobacteria - Present status and future prospects. OECD/OCDE, Paris, 1997. p.94-101.

125. Pierson III, L.S.; Gaffney, T.; Lam, S.; Gong, F. Molecular analysis of gene encoding phenazine biosynthesis in the biological control bacterium Pseudomonas aureofaciens 30-84. FEMS Microbiol. Lett., 134, 299-307, 1995.

126. Pierson III, L.S.; Kepenne, V.D.; Wood, D.W. Phenazine antibiotic byosynthesis in Pseudomonas aeureofaciens 30-84 is regulated by PhzR in response to cell density. J. Bacteriol., 176, 3966-3974, 1994.

127. Pillai, B.V.S.; Swarup, S. Elucidation of the flavonoid catabolism pathway in Pseudomonas putida PML2 by comparative metabolic profiling. Appl. Environ. Microbiol., 68(1), 143-151, 2002.

128. Raaijmakers, J.M.; Vlami, M.; De Souza, J.T. Antibiotic production by bacterial biocontrol agents. Antonie Leeuwenkoek, 81, 537-547, 2002 .

129. Raaijmakers, J.M.; Weller, D.M. Exploiting genotypic diversity of 2,4- diacetylphloroglucinol producing Pseudomonas spp.
Characterization of superior root colonizing $P$. fluorescens strains Q8r1-96. Appl. Environ. Microbiol., 67(6), 2545-2554, 2001.

130. Raaijmakers, J.M.; Weller, D.M.; Thomashow, L.S. Frequency of antibiotic- producing Pseudomonas spp. in natural environments. Appl. Environ. Microbiol., 63(3), 881-887, 1997.

131. Rainey, P.B. Adaptation of Pseudomonas fluorescens to the plant rhizosphere. Environ. Microbiol., 1(3), 243-257, 1999.

132. Ramette, A.; Moënne-Loccoz, Y.; Défago, G. Prevalence of fluorescent Pseudomonads producing antifungal phloroglucinols and/ or hydrogen cyanide in soils naturally suppressive or conducive to tobacco black root rot. FEMS Microbiol. Ecol., 44, 35-43, 2003.

133. Raymond, R.N.; Muller, G.; Matzanke, F. Complexation of iron by siderophores. A review of their solution and structural chemistry and biological function. Top. Curr. Chem., 123, 49-102, 1984.

134. Reimmann, C.; Valverde, C.; Kay, E.; Haas, D. Posttranscriptional repression of $\mathrm{GacS} / \mathrm{GacA}$-controlled genes by the RNA-binding protein RsmE acting together with RsmA in the biocontrol strain Pseudomonas fluorescens CHAO. J. Bacteriol., 187, 276-285, 2005.

135. Ron, E.Z.; Rosenberg, E. Natural roles of biosurfactants. Environ Microbiol., 3, 229-236, 2001.

136. Rumjanek, N.G.; Fonseca, M.C.C.; Xavier, G.R. Quorum sensing em sistemas agrícolas: comportamento multicelular em procariotos via comunicação intercelular. Rev. Biotecnol., Ciênc. Desenvol., 33, 35$50,2004$.

137. Schroth, M.N.; Hancock, J.G. Disease suppressive soil and rootcolonizing bacteria. Science, 216(25), 1376-1381, 1982.

138. Sharma, A.; Sahgal, M.; Johri, B.N. Microbial communication in the rhizosphere:Operation of quorum sensing. Curr. Sci., 85(8), 1164 1172,2003

139. Silva, F.A.G.; Peixoto, C.N.; Assis, S.M.P.; Mariano, R.L.R.; Padovan, I.P. Potencial de Pseudomonas spp. fluorescentes para biocontrole de Alternaria ricini em manoneira. Braz. Arch. Biol. Technol., 41, 91-102, 1998

140. Siqueira, J.O.; Franco, A.A. Biotecnologia do solo: Fundamentos e perspectivas. Gráfica Nagy Ltda, São Paulo, 1988. 235p.

141. Sørensen, J.; Jensen, L.E.; Nybroe, O. Soil and rhizosphere as habitats for Pseudomonas inoculants: new knowledge on distribution, activity and physiological state derived from micro-scale and single-cell studies. Plant Soil, 232, 97-108, 2001

142. Sørensen, J.; Skouv, J.; Nybroe, O. Rapid identification of environmental isolates Pseudomonas aeruginosa, P. fluorescens and $P$. putida by SDS PAGE analysis of whole- cell protein patterns FEMS Microbiol. Ecol., 101, 41-50, 1991.

143. Spiers, A.J.; Buckling, A.; Rainey, P.B. The causes of Pseudomonas diversity. Microbiology, 146, 2345-2350, 2000.

144. Stackerbrandt, E.; Rainey, F.A. Partial and complete 16 S rDNA sequences, their use in generation of $16 \mathrm{~S}$ rDNA phylogenetic trees and their implications in molecular ecological studies. In: Molecular Microbial Ecology Manual, Kluwer Academic Publishers, Holanda, 1995, vol.3.1.1, p.1-17.

145. Stanghellini, M.E.; Miller, R.M. Biosurfactants: their identity and potential efficacy in the biological control of zoosporic plant pathogens. Plant disease, 81, 4-12, 1997.

146. Steenhoudt, O.; Vanderleyden, J. Azospirillum, a free-living nitrogenfixing bacterium closely associated with grasses: genetic, biochemical and ecological aspects. FEMS Microbiol. Rev., 24, 487-506, 2000

147. Suslow, T.V.; Schroth, M.N. Rhizobacteria of sugar beets: effects of seed application and root colonization on yield. Phytopathology, 72, 199-206, 1982

148. Thomashow, L.S.; Mavrodi, D.V. The genetics and regulation of antibiotic production by PGPR. In: Ogoshi, A.; Kobayashi, K.; Homma, F.; Kondo, N.; Akino, S. Plant growth-promoting rhizobacteria - Present status and future prospects. OECD/OCDE, Paris, 1997, p.108-114.

149. Thomashow, L.S.; Weller, D.M. Current concepts in the use of introduced bacteria for biological disease control: mechanisms and 
Botelho, G.R. and Mendonça-Hagler, L.C.

antifungal metabolites. In: Stacey, G.; Keen, N. (eds). Plant-Microbes Interactions. Chapman \& Hall Publ., Nova York, 1995, v.1, p.187-235.

150. Thomashow, L.S.; Weller, D.M.; Bonsall, R.F.; Pierson III, L.S. Production of the antibiotic phenazine-1-carboxylic acid by fluorescent Pseudomonas species in the rhizosphere of wheat. Appl. Environ. Microbiol., 56, 908-912, 1990.

151. Thomashow, L.S.; Weller, D.M. Role of a phenazine antibiotic from Pseudomonas fluorescens in Biological Control of Gaeumannomyces graminis var. tritici. J. Bacteriol., 170(8), 3499-3508, 1988.

152. Thrane, C.; Olsson, S.; Nielsen, T.H.; Sørensen, J. Vital fluorescent strains for detection of stress in Pythium ultimum and Rhizoctonia solanii challeged with viscosinamide from Pseudomonas fluorescens DR54. FEMS Microbiol. Ecol., 30, 11-23, 1999.

153. Troxler, J.; Zala, M.; Natsch, A.; Moënne-Loccoz, Y.; Défago G. Autecology of the biocontrol strain Pseudomonas fluorescens CHA0 in the rhizosphere and inside roots at later stages of plant development. FEMS Microbiol. Ecol., 23, 119-130, 1997.

154. Van Loon, L.C.; Bakker, P.A.H.M.; Pieterse, C.M.J. Systemic resistance induced by rhizobacteria. Аnпи. Rev. Phythopathol., 36, 453-483, 1998.

155. Van Peer, R.; Niemann, G.J.; Schippers, B. Induced resistance and phytoalexin accumulation in biological control of fusarium wilt carnation by Pseudomonas sp. strain WCS417r. Phytopathology, 81, 728-734, 1991.

156. Van Peer, R.; Schippers, B. Plant growth responses to bacterization with selected Pseudomonas spp. strains and rhizosphere microbial development in hydroponic cultures. Can. J. Microbiol., 35, 456463, 1989.

157. Versalovic, J.; Koeuth, T.; Lupski, J.R. Distributition of repetitive DNA sequences in eubacteriaand application of bacterial genomes. Nucleic Acid Res., 19, 6823-6831, 1991.

158. Voisard, C.; Keel, C.; Haas, D.; Défago, G. Cyanide production by Pseudomonas fluorescens helps suppress black root rot of tobacco under gnotobiotic conditions. EMBO J., 8, 358-361, 1989.
159. Walsh, U.F.; Morrissey, J.P.; O'Gara, F. Pseudomonas for biocontrol of phytopathogens: from functional genomics to commercial exploitation. Curr. Opin. Biotechnol., 12, 289-295, 2001.

160. Weisbeek, P.J.; Gerrits, H. Iron and biocontrol. In: Stacey, G. and Keen, N.T. Plant-microbe interactions. APS Press, St. Paul, 1999, v.4, p.217-250.

161. Weller, D.M.; Raaijmakers, J.M.; Thomashow, L.S. The rhizosphere ecology of antibiotic-producing pseudomonads and their role in takeall decline. In: Ogoshi, A.; Kobayashi, K.; Homma, F.; Kondo; N.; Akino, S. Plant growth-promoting rhizobacteria - Present status and future prospects. OECD/OCDE, Paris, 1997, p.58-65.

162. Weller, D.M.; Thomashow, L.S. Current challenges in introducing beneficial microorganisms in to the rhizosphere. In: O'gara; F.; Dowling, D.N.; Boesten, B. Molecular Ecology of Rhizosphere microorganisms. VCH, Weinheim, 1994, p.1-17.

163. Weller, D.M.; Cook, R.J. Suppression of take-all of wheat by seedtreatment with fluorescent pseudomonads. Phytopathology, 73, 463469, 1983.

164. Wilson, D. Endophytes - The evolution of a term, and classification of its use and definition. Oikos, 73, 274-266, 1995.

165. Woese, C.R. Bacterial evolution. Microbiol. Rev., 51, 221-271, 1987.

166. Wood, D.W.; Pierson III, L.S. The PhI gene of Pseudomonas aureofaciens $30-84$ is responsible for the production of a diffusible signal required for phenazine antibiotic production. Gene, 168, 4953, 1996.

167. Whipps, J.M. Carbon economy. In: Lynch, J.M (eds.). The rhizosphere. John Wiley \& Sons Ltd., Chichester, 1990, p.59-98.

168. Zhang, Z.; Pierson III. A second quorum-sensing system regulates cell surface properties but not phenazine antibiotic production in Pseudomonas aureofaciens. Appl. Environ. Microbiol., 67, 43054315, 2001.

169.Zhou, T.; Paulitz, T.C. Induced resistance in the biocontrol Phythium aphanidermatum by Pseudomonas spp. on cucumber. $J$. Phytopathol., 142, 51-63, 1994. 